\title{
The Use of Audiobooks as Part of Digital Literacies in Indonesian Students' Perception
}

\begin{abstract}
Asmi Rusmanayanti ${ }^{1 *}$
*Eotvos Lorand University

Email: Indonesia.asmi@gmail.com

ABSTRACT

The emerging concept of digital literacy has much contended nowadays. High or low technologies support varied applications and tools in the EFL context to facilitate teaching and learning English activities. The requirement to improve the capability and be up to date with the newest Information and Communication Technologies (ICT) is crucial, including for Indonesian students. Learning a foreign language is an integrated process of the four language skills. That integration can be blended and modified using technology, such as Audiobooks in extensive reading activities classes. This qualitative study was conducted to explore the students' perception of using Audiobooks to vary the learning media that the students can access. There were twenty random students at the Faculty of Teacher Training and Education were selected as participants. A set of open-ended questionnaires was distributed, and then five samples were chosen to join an in-depth interview session for acquiring detailed results. A content analysis was used to analyze the responses of the participants. The students mentioned the use of audiobooks was a breakthrough in reading and improving listening skills at the same time. The students also mentioned that they had some challenges while listening to the audiobooks; however, they could find good solutions and even shared their thought on certain points about this activity.
\end{abstract}

Keywords: Audiobooks, Digital Literacies, EFL, Indonesia, MALL

\section{INTRODUCTION}

When thinking of English as a language of wider communication, reading plays a significant role in most professions. In reading a passage, the reading material written in English is a heavy load of difficult words and expressions that are not necessarily retained even after the students have read them and checked their meaning in the dictionary many times. A study of the effects of audiobooks on listening comprehension and determining students' views about using audiobooks in regular classroom settings. Kartal and Simsek [10] mentioned that the opinion survey was used to understand students' experiences and perspectives of using audiobooks in foreign language learning classrooms. The outcomes have proven that students develop positive attitudes towards audiobooks and suggest that both students and teachers integrate audiobooks into the regular classroom practice, assign homework based on audiobook usage, and set up listening and pronunciation contest based on the audio text. It indicated that audiobooks can be used with students at all proficiency levels.

Furthermore, the increased interest in using such an intervention could be directly tied to audiobooks' increased access and popularity. Moore and Cahill [14], mentioned that research exploring audiobooks is necessary for determining if or how engagement with audiobooks really does affect adolescent users in meaningful ways. With the increased popularity, access, and availability of high-quality literature in an audio format, educators are now increasingly interested in the validity of the use of audiobooks in literacy instruction.

This research is expected to provide insight into students' perception of the use of Audiobooks as part of digital literacies in Indonesia. This research is also likely to be a source to those who want to research the same topic. 


\section{LITERATURE REVIEW}

The use of ICT offers a chance to make sure that the reading activity, for example, through Audiobooks, can involve other language skills, e.g. reading and listening skills. Learners should enjoy reading, feel motivated to read, have access to exciting texts, and be involved in activities like listening to a story, independent reading, and shared reading. At this recent time, the rapid development of mobile devices led to a new abbreviation, which we called MALL (Mobile Assisted Language Learning). Kukulska-Hulme [12] defined several MALL characteristics related to portability and mobility, social connectivity, context-sensitivity, and individuality. It is possible to integrate MALL in the teaching and learning process, and one of its potential applications is the use of audiobooks which are more convenient for the students to search on their cellphones. Using the MALL will be easier for them to access the audiobook anytime they want to hear it without limited restrictions due to place and the preferable content. Piniel and Albert [16] mentioned that essential sources of the motivational potential associated with virtual environments are the adaptations to learners' individual needs that can be made, the possibilities for immediate feedback, and the facilitation of collaborative learning.

Furthermore, Jones-Kavalier and Flannigan [9] define digital literacy as the multiple formats from extensive sources which are presented through computers as well as one's capability for performing tasks effectively within a digital environment. Additionally, digital literacy can also be defined as an awareness, attitude, and also capability for utilizing digital tools and facilities to achieve various goals that requires mastery of high-level critical thinking skills [21]. These statements are further elaborated by Godswill and Adolphus [6] who state that to be considered digitally literate, one had to possess access to a vast range of practices along with cultural resources that could be applied to digital tools.

In addition, Hybrid learning is a learning model which combines and develops face-to-face (F2F) instructions through computer mediated means that is continuously expanding since many educators are creating various online environments for their students [22]. Students' satisfaction has become an essential part of hybrid learning [13] and could be achieved through the positive impact of the instructors' skills and the kind of technology being utilized [2] as well as the students' attitude toward the hybrid learning as well as their ability in operating the computers [15].

In line with digital literacy, blended learning is any thoughtful combination of face-to-face (F2F) learning and online or computer mediated instructions [7] despite the online spent time could be varied depending on the aims [19].. It was resolute that this kind of learning generated better academic results compared to learning that only delivered through online means [18]. Moreover, students prefer blended learning over the traditional one [1] and there are various instances showcase that this type of learning is more effective in enhancing students' critical thinking capabilities along with their interests toward particular subjects [11] including English as a foreign language (EFL).

There are two types of cognitive processes involved in second or foreign language use, according to Shiffrin and Schneider, cited in Kartal \& Simsek, [10] namely controlled and automatic processes. The first type requires particular attention to control, and hence processing is slow while the second type relies on cognitive activity without control intentionally. When the process is more automatic, it is easier to execute. For second language learners, speech rate is a prominent problem in listening, therefore audiobooks are potential to facilitate them in following the spoken form and the written form [3]. Since reading aloud is also a good way to introduce new vocabulary and concepts, it provides a fluent model. Audiobooks gives them the access to the literature they cannot read independently. These can also be an essential learning sources in reading programs.

Some audio book-based reading strategies can aid those with reading difficulties concerning vocabulary. If the reading difficulties are down to a limited vocabulary, audiobooks are an excellent tool to recognize and learn vocabulary since learners will practice those skills. Wittkower [20] mentioned that the audiobook, as an audio performance of the written word, contains specific meanings of the written words without the affordance of nonlinear options for reader engagement. The richness of human speech seems to be sufficient compensation to support comprehension, not only the guiding rhythms of speech reintroduced, substituting for punctuation marks - their pale written equivalent - but additionally, every word is made replete with meaning through its intonation.

\section{RESEARCH DESIGN AND METHODOLOGY}

\subsection{Research Method}

The design of this research was descriptive with a qualitative approach. This method was chosen because the purpose of the qualitative study was to describe the empirical reality behind the phenomenon in-depth, in detail, and thoroughly. It means that the data collected was not in the form of numbers, and in this study, the necessary data collected by using an open-ended questionnaire. The questionnaire was also chosen because of the accessibility to the respondents due to the 
time differences and instability of the internet access for doing an interview.

Another reason for opting for a qualitative study was a deeper understanding of the student's perception of using audiobooks to learn EFL. Based on the objectives of this study and the theoretical background reviewed, the following research questions were formulated:

RQ1: What are English Language Education Department students' perceptions of using Audiobooks as an alternative media for learning EFL?

RQ2: How do the students use Audiobooks?

RQ3: What are the challenges while listening to an audiobook as media for learning EFL?

\subsection{Participants of the Research}

The participants of this research are university students. The researcher implemented a random sampling technique to make the collected data more reliable. Hence, the chosen participants were 20 students: 9 male students and 11 female students at 22 years old-English Education Department students from the Faculty of Teacher's Training and Education in Indonesia.

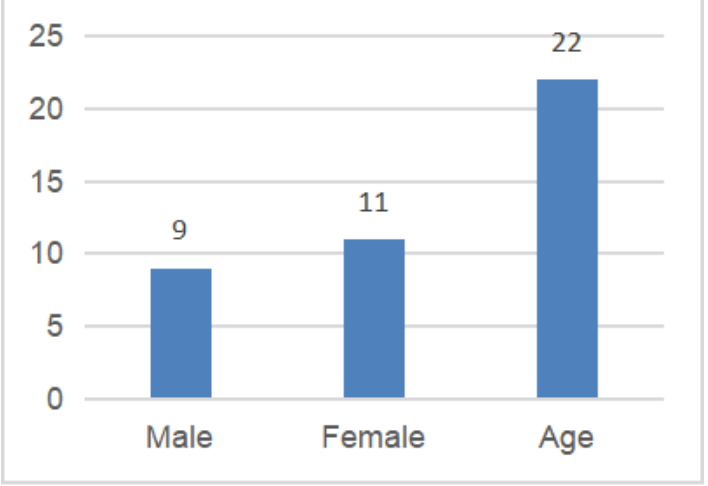

Figure 1. Participants of Audiobooks as a media in learning EFL

\subsection{Research Instrument}

In this research, the instrument used by the researcher was an open-ended questionnaire. The researcher chose an open-ended questionnaire over the closed one since an open-ended questionnaire gives more insight into participants' perceptions of the topic. In addition, this instrument had decided to solve the problems in collecting data. There is a big gap in time differences, and most students have problems with internet connection in some rural regions. The form of data collection was by e-mail sent to some students, and then they informed their friends. The piloting of the instrument was in March 2021 to few students, and only minor changes were needed in terms of numbering and broke the questions, not into a general one. No problem arose during the piloting and when the data collection since the researcher already gave suitable time for them to fill the questionnaire and sent it to their coordinator friend. The questionnaire can be seen in Appendix A.

\subsection{Data Collection and Analysis}

The questionnaire was developed in English since all the participants are English Language Education Department students. The participants were allowed to express their ideas and opinions in an open-ended questionnaire. After all the questionnaires were returned, content analysis was used to analyze the data. In content analysis, counting is an important characteristic. Each time a unit in a pertinent category is found, it is "counted". The coding process must be numbered, mainly the frequency of certain words or phrases or other manifest content (Frankel et al., 2012). The content analysis was used to categorize the participants' responses which might be varied in terms of the diction of the words, but the main point of what they wanted to share was similar. Therefore, the content analysis was needed to categorize it and further analyze it based on the data.

Descriptive statistical procedures are helpful to summarize the data and assist the researcher in interpreting what they reveal. A common way to interpret content analysis data is using frequencies (i.e., the number of specific incidents found in the data) and the percentage and/or proportion of occurrences to total occurrences. In addition, the use of codes and themes aids in organizing content and arriving at a narrative description of findings.

The data were collected in four weeks, from March 2021 to April 2021. The questionnaire was sent to some of the participants, and then they spread it to some of their friends at the same level or year.

\section{RESULTS AND DISCUSSION}

\subsection{Research Results}

When asked about the frequency of using audiobooks, $55 \%$ of the participants indicated that this was the first time that they used an audiobook. Compared, $45 \%$ of them already used Audiobooks one or two times before this occasion (see Table 1). 
Table 1. Number of times of using an audiobook by the participants

\begin{tabular}{|l|c|c|}
\hline Theme & $\begin{array}{c}\text { Number of } \\
\text { mentions }\end{array}$ & $\begin{array}{c}\% \text { of total } \\
\text { mentions }\end{array}$ \\
\hline First time & 11 & $55 \%$ \\
\hline Second time & 7 & $35 \%$ \\
\hline Third time & 2 & $10 \%$ \\
\hline In total & $\mathbf{2 0}$ & $\mathbf{1 0 0} \%$ \\
\hline
\end{tabular}

When asked to describe their audiobook, $95 \%$ of the participants chose fiction audiobooks with different genres and duration. Most of the participants chose Fiction instead of non-fiction because it could make them more relaxed and enjoy the process of using audiobooks as an alternative media in learning English. It is a new way of learning besides learning in English classes (see Table 2).

Table 2. Kinds of the Audiobooks mentioned by the participants

\begin{tabular}{|l|c|c|}
\hline Genre & $\begin{array}{c}\text { Number of } \\
\text { mentions }\end{array}$ & $\begin{array}{c}\% \text { of total } \\
\text { mentions }\end{array}$ \\
\hline Fiction & 19 & $95 \%$ \\
\hline Non-fiction & 1 & $5 \%$ \\
\hline In total & $\mathbf{2 0}$ & $\mathbf{1 0 0} \%$ \\
\hline
\end{tabular}

When asked to describe their process of using Audiobooks activity by the participants, they mentioned various ways. $36 \%$ of the participants used to replay the Audiobooks, $30 \%$ of them did it and had some break time while listening to the audiobook, $18 \%$ of the participants skipped some parts of the audiobook, and $15 \%$ of them listened to the whole thing at once without any break time (see Table 3).

Table 3. Process of using Audiobooks activity by the participants. (May choose more than one option)

\begin{tabular}{|c|c|c|}
\hline Theme & $\begin{array}{c}\text { Number } \\
\text { of } \\
\text { mentions }\end{array}$ & $\begin{array}{c}\% \text { of } \\
\text { total } \\
\text { mentions }\end{array}$ \\
\hline a. Replay the Audiobook & 12 & $36.4 \%$ \\
\hline b. $\quad \begin{array}{l}\text { Have some breaks while } \\
\text { listening }\end{array}$ & 10 & $30.3 \%$ \\
\hline c. $\quad \begin{array}{l}\text { Skip some parts of the } \\
\text { Audiobook }\end{array}$ & 6 & $18.2 \%$ \\
\hline d. $\quad \begin{array}{l}\text { Listen to the whole } \\
\text { thing at once without } \\
\text { any break }\end{array}$ & 5 & $15.2 \%$ \\
\hline$\quad \begin{array}{l}\text { In total } \\
\quad \text { The }\end{array}$ & $\mathbf{3 3}$ & $\mathbf{1 0 0 \%}$ \\
\hline
\end{tabular}

The following tables will describe the detailed activities of the participants in the process of using the Audiobook activity. When the participants replayed the audiobooks, various reasons were mentioned. There were $50 \%$ of the participants replayed the Audiobooks to ensure the storyline, e.g., the characters in the stories, the plot, and the events of the stories. $20 \%$ of the participants mentioned they replayed it because the clarity of the narrator's voice is unclear of the speakers' accent, too fast, or unfamiliarity to use an audiobook. Some participants also mentioned that they replayed the audiobook when they found new vocabularies, the short duration for the audiobook story, or some activities such as listening and reading or writing activities simultaneously (see Table 4a).

When the participants had some breaks while listening to the audiobooks, various reasons were mentioned. Like the previous reason for replaying the Audiobooks, $28 \%$ of the participants needed it to ensure the understanding of the storyline, plots, characters, events of the audiobook story. $24 \%$ of them said because of the time management for other activities and different assignments. Another $24 \%$ of the participants also needed the breaks when they found new vocabularies and searched the meaning. The rest of the participants said they needed the breaks while listening to the audiobook activities because they thought the narrator was too fast and the long duration of the audiobook was over one hour (see Table 4b).

Table 4. Reasons to replay, have some breaks, skip some parts, and listen to the whole audiobook by the participants

\begin{tabular}{|c|c|c|}
\hline Theme & $\begin{array}{l}\text { Number } \\
\text { of } \\
\text { mentions }\end{array}$ & $\begin{array}{l}\% \text { of total } \\
\text { mentions }\end{array}$ \\
\hline $\begin{array}{l}\text { a. Reasons to replay to } \\
\text { the audiobook }\end{array}$ & & \\
\hline $\begin{array}{l}\text { to ensure the storyline, } \\
\text { characters, plot, etc }\end{array}$ & 10 & $50 \%$ \\
\hline unclear; too fast & 4 & $20 \%$ \\
\hline new vocabularies & 2 & $10 \%$ \\
\hline $\begin{array}{l}\text { short duration for } \\
\text { something new }\end{array}$ & 2 & $10 \%$ \\
\hline $\begin{array}{l}\text { careful listening along with } \\
\text { reading or writing }\end{array}$ & 2 & $10 \%$ \\
\hline In total & 20 & $100 \%$ \\
\hline $\begin{array}{l}\text { b. Reasons to have some } \\
\text { breaks while listening } \\
\text { to the audiobook }\end{array}$ & & \\
\hline $\begin{array}{l}\text { to ensure the storyline; } \\
\text { plots, characters, events }\end{array}$ & 5 & $28 \%$ \\
\hline $\begin{array}{l}\text { need to divide the time for } \\
\text { other } \\
\text { activities/assignments }\end{array}$ & 4 & $24 \%$ \\
\hline found new words & 4 & $24 \%$ \\
\hline $\begin{array}{l}\text { when the narrator was too } \\
\text { fast }\end{array}$ & 2 & $12 \%$ \\
\hline long duration to do at once & 2 & $12 \%$ \\
\hline In total & 17 & $100 \%$ \\
\hline $\begin{array}{l}\text { C. Reasons to have some } \\
\text { breaks while listening } \\
\text { to the audiobook }\end{array}$ & & \\
\hline $\begin{array}{l}\text { to make it faster, time } \\
\text { management }\end{array}$ & 4 & $27 \%$ \\
\hline $\begin{array}{l}\text { long duration or narration } \\
\text { of the Audiobook }\end{array}$ & 4 & $27 \%$ \\
\hline $\begin{array}{l}\text { to know the essence of the } \\
\text { story }\end{array}$ & 3 & $20 \%$ \\
\hline
\end{tabular}




\begin{tabular}{|c|c|c|}
\hline \multirow{3}{*}{$\begin{array}{l}\text { hard to understand the } \\
\text { narrator speech } \\
\text { already read the actual } \\
\text { book } \\
\text { In total }\end{array}$} & 2 & $13 \%$ \\
\hline & 2 & $13 \%$ \\
\hline & 15 & $100 \%$ \\
\hline $\begin{array}{l}\text { d. Reasons to listen to the } \\
\text { whole thing at once } \\
\text { without any break to } \\
\text { the audiobook }\end{array}$ & & \\
\hline $\begin{array}{l}\text { to know/Easier to } \\
\text { understand the story }\end{array}$ & 3 & $33.4 \%$ \\
\hline $\begin{array}{l}\text { to practice the English } \\
\text { skills/English components }\end{array}$ & 3 & $33.4 \%$ \\
\hline to avoid distraction & 2 & $22.2 \%$ \\
\hline $\begin{array}{l}\text { to compare with other } \\
\text { authors the same story }\end{array}$ & 1 & $11.0 \%$ \\
\hline In total & 9 & $100 \%$ \\
\hline
\end{tabular}

Another way of listening to the audiobook activity involves skipping some parts of the audiobook for several reasons. Most of the participants, $27 \%$ of them, did it for shortening the listening time and arranged the time management. The same percentage of the participants also skipped some parts of the Audiobooks due to the long duration or narration. $20 \%$ of the participants skipped part by part because they wanted to know the essence or points of the story faster, leading to more comprehension of the story, and it was essential to finish the story (see Table 4c).

There were also some of the participants who listened to the whole thing at once without any break. The participants' two most frequently mentioned reasons were that it was easier to know or understand the story. It was a good way to practice the English skills or components, $33.34 \%$ for each participant's total. Another reason, $22 \%$ of the participants, was to avoid distraction during the listening process (see Table 4d).

During the audiobook activity, many challenges were mentioned by the participants. The most significant difficulties were that $32 \%$ of the participants related to the unfamiliar words while listening to the Audiobooks, and $26 \%$ of the participants mentioned that they needed to focus more on the listening activity. The other reasons were related to the story understanding and the long duration of the story. However, some of the participants also mentioned that finding a kind of audiobook genre, e.g. romance, thriller, fable, - and unclear or the narrator's voice during listening to the audiobook was also challenges for them. There was also an internet connection challenge because the participant stayed in a remote place and had an unstable internet connection due to the weather connection (see Table 5).
Table 5. Challenges of using Audiobooks by the participants

\begin{tabular}{|l|c|c|}
\hline Theme & $\begin{array}{c}\text { Number } \\
\text { of } \\
\text { mentions }\end{array}$ & $\begin{array}{c}\% \text { of total } \\
\text { mentions }\end{array}$ \\
\hline $\begin{array}{l}\text { lack of } \\
\text { vocabulary/unfamiliar } \\
\text { words }\end{array}$ & 10 & $33 \%$ \\
\hline $\begin{array}{l}\text { need to focus on the story } \\
\text { of the Audiobook }\end{array}$ & 8 & $26 \%$ \\
\hline $\begin{array}{l}\text { understanding the } \\
\text { audiobook story of the }\end{array}$ & 4 & $13 \%$ \\
\hline $\begin{array}{l}\text { long duration } \\
\text { audiobook story }\end{array}$ & 2 & $6 \%$ \\
\hline to find the Audiobook narrator's & 2 & $6 \%$ \\
\hline $\begin{array}{l}\text { changes of the } \\
\text { voice; unclear }\end{array}$ & 1 & $3 \%$ \\
\hline slow internet connection & $\mathbf{3 1}$ & $\mathbf{1 0 0 \%}$ \\
\hline In total & & \\
\hline
\end{tabular}

In responding to the audiobook's challenges, $29 \%$ of the participants replayed, slowed down or paused the Audiobooks. It could be understood that the participants need to do those activities, replayed and the like because the narrator spoke at a standard speed or even faster at a particular part of the story while some of the participants still tried to catch the words or phrases to comprehend the stories. The following most frequent response to challenges mentioned by the $21 \%$ of participants was dictionary usage while simultaneously learning the pronunciation of the words. Even though most participants understood that they did not need to understand the text word by word, they needed to check the new words to learn how to pronounce the words correctly and apply them in a natural context. They were responding to the challenges by reading the subtitle while listening carefully to the audiobook. Some of them also mentioned that making notes or summaries helped them understand the story better than just listening from the beginning until the end. They also mentioned other devices to help them listen well and search the Audiobook by YouTube or podcast. In addition, preparing a spicy meal and drinks could help them avoid boredom and sleepiness during the listening audiobook activity (see Table 6).

Table 6. Participants' responses to the challenges of using audiobook

\begin{tabular}{|l|c|c|}
\hline Theme & $\begin{array}{c}\text { Number of } \\
\text { mentions }\end{array}$ & $\begin{array}{c}\% \text { of total } \\
\text { mentions }\end{array}$ \\
\hline $\begin{array}{l}\text { replay/slowdown } \\
\text { the audiobook }\end{array}$ & 14 & $29 \%$ \\
\hline $\begin{array}{l}\text { use dictionary/ learn the } \\
\text { pronunciation }\end{array}$ & 10 & $21 \%$ \\
\hline read the subtitle focus/listen & 5 & $13 \%$ \\
\hline $\begin{array}{l}\text { always } \\
\text { carefully }\end{array}$ & 5 & $10 \%$ \\
\hline $\begin{array}{l}\text { understand the story, make } \\
\text { notes/resume }\end{array}$ & 4 & $8 \%$ \\
\hline $\begin{array}{l}\text { use devices; a speaker, a } \\
\text { headset, Wi-Fi }\end{array}$ & & \\
\hline
\end{tabular}




\begin{tabular}{|l|c|c|}
\hline $\begin{array}{l}\text { Search the Audiobook by } \\
\text { YouTube/podcast }\end{array}$ & 2 & $4 \%$ \\
\hline prepare a spicy meal, drink & 2 & $4 \%$ \\
\hline In total & 48 & $100 \%$ \\
\hline
\end{tabular}

Many audiobooks can be accessed from the internet; many participants preferred to read the real book instead of listening to Audiobooks. $60 \%$ of the participants chose to read real English books, and $40 \%$ preferred listening to an audiobook (see table 7 and table 8 will explore more the participants' reasons for their preferences due to Audiobooks).

Table 7. Preferences of using Audiobooks by the participants

\begin{tabular}{|l|c|c|}
\hline Theme & $\begin{array}{c}\text { Number of } \\
\text { mentions }\end{array}$ & $\begin{array}{c}\% \text { of total } \\
\text { mentions }\end{array}$ \\
\cline { 2 - 3 } reading the real book & 12 & $60 \%$ \\
\hline listening to the Audiobook & 8 & $40 \%$ \\
\hline In total & 20 & $100 \%$ \\
\hline
\end{tabular}

For the reading, $31 \%$ of the participants preferred the actual book because of more convenience. Having the real object (the books) in front of them, 27\% of the participants mentioned that it made them easier to focus, and $19 \%$ understood the story better and could be more imaginative. In addition, having the real book made $15 \%$ of them easier to find the new vocabulary because they could see the spelling of the words, which was easier to find the meaning in the dictionary. Another reason for the preference for the real book was the level of the perception of the participants' English skills. Some of them confessed that their listening skills were not advanced (see Table 8a).

Table 8. Preferences' reasons for reading the actual book by the participants

\begin{tabular}{|l|c|c|}
\hline Theme & $\begin{array}{c}\text { Number } \\
\text { of } \\
\text { mention } \\
\text { s }\end{array}$ & $\begin{array}{c}\% \text { of } \\
\text { total } \\
\text { ment } \\
\text { ions }\end{array}$ \\
\hline $\begin{array}{l}\text { Preferences' reasons for } \\
\text { reading the actual book }\end{array}$ & 8 & $31 \%$ \\
\hline more convenient & 7 & $27 \%$ \\
\hline $\begin{array}{l}\text { easier to understand the story } \\
\text { and focus }\end{array}$ & 5 & $19 \%$ \\
\hline can be more imaginative & 4 & $15 \%$ \\
\hline $\begin{array}{l}\text { improve and easier to find the } \\
\text { new vocabularies meaning }\end{array}$ & 2 & $8 \%$ \\
\hline not very good at listening & $100 \%$ \\
\hline In total reasons for & & \\
\hline $\begin{array}{l}\text { Preferences' } \\
\text { listening to the audiobook }\end{array}$ & 6 & $35 \%$ \\
\hline $\begin{array}{l}\text { can save time and do other } \\
\text { activities }\end{array}$ & 5 & $29 \%$ \\
\hline $\begin{array}{l}\text { simpler, refreshing, preferable } \\
\text { than reading the real book }\end{array}$ & & \\
\hline
\end{tabular}

\begin{tabular}{|l|c|c|}
\hline can imagine the story listening and & 3 & $18 \%$ \\
\hline $\begin{array}{l}\text { improve } \\
\text { pronunciation }\end{array}$ & 3 & $18 \%$ \\
\hline In total & $\mathbf{1 7}$ & $\mathbf{1 0 0 \%}$ \\
\hline
\end{tabular}

The participants mentioned four main reasons for listening to audiobooks instead of reading actual books. $35 \%$ of the participants mentioned that this activity could save time, and they could also do other activities simultaneously. It was an effective and efficient way of learning EFL. $29 \%$ of the participants said that Audiobooks were simpler, refreshing, and preferable to real books. The rest of the participants said they could imagine the story because some audiobooks also had some background music. This music influenced their mood and imagination, especially the adventurous tale. The last reason was to improve their listening and pronunciation (see Table $8 \mathrm{~b}$ ).

An audiobook is an exciting way of EFL learning activity. $30 \%$ of the participants said that Audiobooks were simpler, more efficient, enjoyable, and relaxing. $19 \%$ of the participants mentioned that audiobooks had many advantages and a new way of learning EFL. $11 \%$ said that they love audiobook stories, and it was a good way for an auditory learner. However, the use of audiobooks also gave challenges to the participants. $17 \%$ of the participants mentioned they needed bigger efforts than reading actual books; hence, they replayed it few times to understand the story. And by this, $6 \%$ of the participants mentioned that they needed to focus almost all the time, which was not easy (see Table 9).

Table 9. Reflection/Summary of using Audiobooks by the participants

\begin{tabular}{|l|c|c|}
\hline Theme & $\begin{array}{c}\text { Number of } \\
\text { mentions }\end{array}$ & $\begin{array}{c}\% \text { of total } \\
\text { mentions }\end{array}$ \\
\hline $\begin{array}{l}\text { an audiobook is simpler, } \\
\text { more efficient, enjoyable, } \\
\text { relaxing }\end{array}$ & 19 & $30 \%$ \\
\hline $\begin{array}{l}\text { advantages to improve } \\
\text { English } \\
\text { skills/components, a new } \\
\text { way of learning }\end{array}$ & 12 & $19 \%$ \\
\hline $\begin{array}{l}\text { need a lot of effort, replay, } \\
\text { challenging }\end{array}$ & 11 & $18 \%$ \\
\hline $\begin{array}{l}\text { unfamiliar new vocabs } \\
\text { problems, learn new } \\
\text { vocabs }\end{array}$ & 10 & $16 \%$ \\
\hline $\begin{array}{l}\text { love the story from the } \\
\text { Audiobook }\end{array}$ & 7 & $11 \%$ \\
\hline $\begin{array}{l}\text { need to stay focus all the } \\
\text { time }\end{array}$ & 4 & $6 \%$ \\
\hline an auditory learner & $\mathbf{6 4}$ & $\mathbf{1 0 0 \%}$ \\
\hline In total & & \\
\hline
\end{tabular}

\subsection{Discussion}

From the participants' responses summarised in Table 1 to Table 9 above, it can be concluded that 
Audiobooks are a new interesting and challenging way of learning EFL. As an answer to RQ1, concerning the English Language Education Department students' perceptions on the use of audiobook as an alternative media for learning EFL, an audiobook is a new media for learning EFL for most of the participants and the students' Faculty of Teachers' Training and Education, English Language Education Department. Even though they face challenges and need to focus most of the listening time, the students' responses agreed this activity is a new engaging, relaxing, and simpler way to improve their English, especially listening and reading English skills. It is a new way to learn and practice their pronunciation and enhance their new vocabulary and learn from the context of the words in use. They love the stories in the Audiobooks because most of them choose the fiction ones and choose based on their preferences. Some participants preferred to read from real books, making them more comfortable holding the real object in their hand. They find it easier to recognize the new vocabulary because it is already written for the correct spelling. It is easier for them to see the meaning in the dictionary. This comment might reflect that some of the respondents' listening skills are still not advanced.

On the other hand, even though all participants agreed that audiobooks are an attractive alternative media in learning EFL, $60 \%$ of the participants still preferred to read from an actual book. In comparison, 40 $\%$ of them preferred the audiobook instead of reading actual books. It seems that the familiarity of the audiobook and a real book can influence the students' preferences. Since most participants were new to this kind of application and approach in learning EFL, some still need the actual book because it would be easier for them to see the new words and find their meaning in their dictionary. In addition, the student's learning styles, e.g., visual or auditory students, also can influence their preferences. By reading from the real books, some of them said that they could be more confident and could be more imaginative in creating the image of the fictional characters in their mind. Another reason the students prefer the actual book instead of the audiobook because they have a problem in listening skill level, either because of lack of vocabulary, difficulty comprehending the narrators' pronunciation, or difficulty focusing on a certain amount of time.

The following quotations indicate the students' preferences for reading actual books. It was the original notes from one of the students and might find some mistakes in it, but the content of the message is the concern of this research:

I love reading, and it's my hobby, so I would prefer to read the book instead of listening to the audiobook. The reason is simple. I like using my imaginations, and that's all I get when I read a book. When I listen to the audiobook, I can't use my imagination as much as when I read books because of concentration in listening to the story will be divided; you have to imagine and have to listen at the same time. It's difficult for me. (Student 1).

On the contrary, those who preferred audiobooks instead of actual books said it could save time and more refreshing than the usual reading activity. It could be understood that audiobooks are engaging because the intonation of the narrator and the background music of some audiobooks make it easier for the participants to imagine the real situation of the story and the excited, angry, happy, thrilling feelings. The following quotations indicate the positive contribution of the audiobook. It was the original notes from one of the students and might find some mistakes in it, but the content of the message is the concern of this research:

It was very fascinating to hear. I was very indulging in the voice and story told by the reader; it makes me very curious furthermore into these kinds of literary genres. But the best part was how the reader was retelling the story in a unique and odd but fascinating way; the feeling that I get when listening to this audiobook was excited mixed with calming feeling in a way that I very much liked. (Student 2).

Listening to audiobooks improves your reading and speaking accuracy and fluency. While the narrator(s) narrates the book, you can notice and learn how he/she is pronouncing different words. You can save a good amount of time by multitasking. (Student 3)

RQ2 enquired about the way the students used the Audiobooks. There are four ways that the students used them, and some of them combine those ways as their styles of listening and learning by using Audiobooks differ. Those ways were; (1) replaying the audiobook, (2) having some breaks time while listening to the audiobook, (3) skipping some parts of the audiobook, and (4) listening to the whole thing at once without any break time. From the reasons provided for those four methods, it can be concluded that the participants are concerned with understanding the storyline of the audiobook. This response appears in all those four ways of usage mentioned by the students. They replay and have some break time while listening to the audiobook due to confusion because of unfamiliar new words from the audiobook stories. Then they take some time to check their dictionaries which helps their understanding of the stories. In addition, these unfamiliar new words cause difficulties that can also lead to a lack of clarity. Thus, respondents need their full attention when they 
listen to the stories. The following quotations indicate the ways of the participants when listening to the audiobook. It was the original notes from one of the students and might find some mistakes in it, but the content of the message is the concern of this research:

I replayed the whole Audiobook two times to make sure I got the plot of the story right and not missing any single part of it. Also, when I felt that the narrator was speaking too fast, I always repeated the audiobook to ten seconds ago to understand what is being explained so that I can write it down if it's the important points of the story. (Student 4)

It was easier for me to took some break times to understand the plot of the story. I also write the essence of the story so that it is easier to understand and retell it. Second, I found some new words that I didn't understand during the audiobook, so I had to pause to found the meaning of the words. (Student 5)

I skipped some parts of the audiobook to make it easier for me to know the essence of the story without spending a lot of time, and helps to improve my time management. And this can also be to eliminate the curiosity of the story in the audiobook. I have also read this story before. (Student 6)

I did it without any break or skipping because I don't really like to postpone the story, I want to hear it completely at the moment. (Student 7).

I heard it full-time without break and reading the script of the actual story, so I gather up two reading skills: listening to the audiobook and reading the text according to the narrator's voice. Why? I love this style because it served as a practice for me to sharpen my listening and reading skills. Honestly, hearing the native speakers narrate the story helped me understand how they pronounce the words, the intonations, and their voice expressions. Reading the actual text gives me the chance to understand it fully without replaying it more than one time. (Student 8)
RQ3 asked about the challenges while listening to the audiobook as media for learning EFL. It is related to their answers to the previous research questions; the students' most significant challenges are related to the unfamiliarity of vocabulary. Hence, the students need more energy to be more focused on listening to the audiobook and understanding the story's content well. Especially for first-time users of the audiobook, finding the genre, e.g., romance, fable, fantasy, thriller, of their favourite story is already a challenge. Furthermore, a stable internet connection also a problem for students who live in remote or rural areas. However, the students also have various ways for overcoming these challenges of using audiobooks. The first one is by replaying, slowing down, pausing, or combining all of these. It helps students because most of them are first-time users of Audiobooks and are not familiar with the standard speed of the narrator's speech. They can also learn the correct pronunciation from native speakers, the narrator and improve their vocabulary of new, unfamiliar words from the story. For unclear sound, they need to be more focused on the words, phrases, or plot of the story, which some can do by using devices such as a headset, a speaker, and Wi-Fi instead of a limited cellphone quota. For finding their preferable audiobook, they search it on Youtube or in podcast content. To make the understanding easier, some also read the story's subtitle, in case there are, or even take notes on the story's events. To avoid boredom or sleepiness, some participants also prepare some food and drinks before and during this activity.

As mentioned earlier, using ICT for teaching EFL and audiobooks to give the students a chance to learn more English out of the class is one of the examples of the adaptations to learners' individual needs. Piniel and Albert [16] mentioned an essential source of the motivational potential associated with virtual environments: the adaptations to learners' individual needs that can be made, the possibilities for immediate feedback, and the facilitation of collaborative learning.

\section{CONCLUSION}

This study attempted to fill a niche in ICT research, especially research connected with an audiobook as an alternative media used in learning EFL. A descriptive qualitative method was applied, and 20 English learners fill in an open-ended questionnaire. Content analysis was also involved in analyzing the participants' responses to determine the students' perceptions of audiobook's use for EFL learners. Since the reading process develops through oral language experiences, audiobooks benefit the students by increasing their comprehension and improving their English language skills gradually while doing other activities 
simultaneously. It is a scaffold that allows students to read beyond their reading level.

Based on the students' perception of this study, many students are still unfamiliar with audiobook use for daily activities. It can be seen from their preferences of reading actual books instead of listening even though they knew that this kind of approach in learning EFL would give them more time and could do multitasking activities. If they were more familiar with using audiobooks and more of their friends also use them, this preference might change as well. In reflection of the audiobook process, from those four types of listening to the audiobooks, the replay and some break time while listening to the audiobook are done by the students because they have confused some unfamiliar new words the audiobook stories. They are concerned about understanding the audiobook storyline because new words difficulties can also make unclear and need full attention when they listen to the stories and not fully understand the stories they heard. There are some challenges mentioned by the participants while doing this audiobook project. Still, all of them have ways to overcome those challenges, even with unique ways such as replaying the audiobooks, prepared food and drinks to avoid sleepiness while listening to a longer audiobook, and the like. The role of the teacher while doing this project play many in this project. Most participants mentioned that a teacher could be a facilitator, resource, or advisor/motivator. They agreed that they need their teacher feedback and positive encouragement to keep them motivated in doing this kind of activity even though audiobooks can be found easily from the internet, the guidance and input from the unreplaceble in the participants' further activities.

Consequently, one possible future research direction could be to investigate the teacher's role in ICT use for EFL teaching and learning activity. Furthermore, the studies might be replicated in the use of other ICT learning applications. As for the teacher, TPACK will link to the use of ICT. Hopefully, the results of this study will be useful for the next researchers, especially to relate the use of ICT to the L2 learning strategies.

\section{REFERENCES}

[1] A. Akbarov, K. Gonen, H. Aydogan, Students' Attitudes Toward Blended Learning in EFL Context. Acta Didactica Napocensia, vol. 11, no. 1, 2018, pp. 61-68. DOI: https://doi.org/10.24193/adn.11.1.5

[2] D. U. Bolliger, T. Martindale, Key Factors for Determining Student Satisfaction in Online Courses, in: Proceedings of International Journal on E-Learning, vol. 3, no. 1, 2004, pp. 61-67.
[3] C. S. Chang, J. Read, The effects of listening support on the listening performance of EFL learners, in: Proceedings of TESOL Quarterly, vol. 40, 2006, pp. 375-397.

[4] R. E. Ferdig, C. Cavanaugh, J.R. Freidhoff, Lessons Learned from Blended Programs: Experiences and Recommendations from the Field. Vienna, VA: Inacol, 2021.

[5] D. R. Garrison, N. D. Vaughan, Blended Learning in Higher Education: Framework, Principles, and Guidelines. San Francisco, California, JosseyBass, 2008.

[6] A. Godswill, P. E. Adolphus, Role of Digital Literacy of Staff for Effective Administration in Open and Distance Learning in Nigeria Universities, in: Proceedings of International Journal of Innovative Information Systems \& Technology Research, vol. 9(2), 7-14.

[7] C. R. Graham, Blended Learning Systems: Definitions, Current Trends, and Future Directions. In C.J. Bonk \& C.R. Graham (Eds.), The Handbook of Blended Learning: Global Perspectives. San Francisco, California: Pfeiffer Publishing, 2006.

[8] B. Isiguzel,The Blended Learning Environment on the Foreign Language Learning Process: A Balance for Motivation and Achievement, in: Proceedings of TOJDE: Turkish Online Journal of Distance Education, vol. 15, 2014, pp. 108-121.

[9] B. R. Jones-Kavalier, S. I. Flannigan, Connecting the Digital Dots: Literacy of the $21^{\text {st }}$ Century, in: Proceedings of Teacher Librarian, vol. 35, no. 3, 2008, pp. 13-16.

[10] G. Kartal, H. Simsek, The Effects of Audiobooks on EFL Students' Listening Comprehension, in : Proceedings of The Reading Matrix: An International Online Journal, vol. 17, no. 1, 2017, pp. 112-123.

[11] O. Korkmaz, U. Karakus, The Impact of Blended Learning on Student Attitudes towards Geography Course and Their Critical Thinking Dispositions and Levels, in: Proceedings of The Turkish Online Journal of Educational Technology, vol. 8, no. 4, 2009, pp. 51-63.

[12] K. Kukulska-Hulme, Will Mobile Learning Change Language Learning?, in: Proceedings of ReCall, vol. 21(2), 2009, pp. 157-165. https://doi.org/10.1017/S0958344009000202

[13] Moore, J. C. (2009). A Synthesis of Sloan-C Effective Practices. Journal of Asynchronous Learning Networks, 13(4), 84-94. 
[14] Moore, J., \& Cahill, M. (2016). Audiobooks: Legitimate 'Reading' Material for Adolescents? School Library Research. 19, 1-17. http://www.ala.org/aasl/slr/volume19/moore-cahill p $1-17$

[15] Onprapat, S. (2019) Predictors of Students' Satisfaction with a Hybrid English Course. Turkish Online Journal of Distance Education, 20(1), 115130.

[16] K. Piniel, A. Albert, The Palgrave Handbook of Motivation for Language Learning. Palgrave Macmilan, 2019.2 DOI: https://doi.org/10.1007/978-3-030-28380-3

[17] M. H. Sivrikaya, An Analysis on Digital Literacy Level of Faculty of Sports Science Students, in: Proceedings of Asian Journal of Education and Training, vol. 6, no. 2, 2020, pp. 117-121. DOI: https://doi.org/10.20448/journal.522.2020.62.117.1 $\underline{21}$

[18] W. R. Slomanson, Blended Learning: A Flipped Classroom Experiment, in: Proceedings of Journal of Legal Education, 64,2014, pp. 93-102.

[19] C. R. Tucker, Blended Learning in Grades 4-12: Leveraging the Power of Technology to Create Student-Centered Classrooms, Thousand Oaks, , CA: Corwin, 2012.

[20] D. E. Wittkower, A Provisional Phenomenology of the Audiobook Philosophy Faculty Publications, vol. 12, no. 13, 2011, pp. 216-231. https://digitalcommons.odu.edu/philosophy_fac_p $\underline{\mathrm{ubs} / 13}$

[21] Yildiz, E. P. (2020). Opinions of Academicians on Digital Literacy: A Phenomenal Study. Cypriot Journal of Educational Sciences, 15(3), 469-478. https://doi.org/10.18844/cjes.v\%vi\%i.4913

[22] M. Zein, Z. M. Nuh, D. Dardiri, Jasril, R. M. Candra, I. Hanafi, M. Thahir, Hybrid Learning in Mathematics Learning: Experimental Study in SMA Negeri 1 Pekanbaru, in: Proceedings of Malikussaleh Journal of Mathematics Learning (MJML), vol. 2, no. 2, 2019, pp. 56-60. https://doi.org/10.29103/mjml.v2i2.2009 